一技術報告一

骨の緻密質の組織構造および Saw Mark の観察における走査型電子顕微鏡の有用性

$$
\text { 中川俊史, 土居正宣 }
$$

愛媛県警察本部刑事部科学捜查研究所

干790-8573 愛媛県松山市南堀端町 2 番地 2

\title{
Usefulness of scanning electron microscope for observation of compact bone structure and saw mark
}

\author{
Toshifumi Nakagawa and Masanori Doi
}

Forensic Sci. Lab., Ehime Pref. Police H.Q.

\author{
2-2, Minamihoribatacho, Matsuyama, Ehime 790-8573, Japan
}

(Received 4 April 2019; accepted 18 September 2019;

Published online 15 November 2019 in J-STAGE DOI: 10.3408/jafst.761)

In forensic anthropology, the histological structure of compact bone is useful for distinguishing human from non-human bone and for age estimation. A saw mark on the bone surface is also analyzed to estimate the implement that cut the bone. However, extensive time and technical proficiency are required to prepare a specimen for obtaining a clear image of the compact bone structure in optical microscopy. Moreover, clear detection of a saw mark is inhibited by the limited focal depth of optical microscopy and by the color tone of bones. The purpose of this study is to evaluate imaging mode of scanning electron microscope (SEM) and preparation of bone specimen to readily obtain a clear image of the compact bone structure and saw mark in a shorter time. In this paper, a transverse section of a long bone was polished to a mirror finish, completed within a few minutes by a simple method, to observe the compact bone structure. In consequence, Haversian canal, bone lacuna, and lamellar structure in the compact bone were clearly observed with compositional (COMPO) image in the backscattered electron mode. Meanwhile, the saw mark was also clearly recognized as a convexo-concave on the transverse section of the long bone with topographic (TOPO) image in the backscattered electron mode. Thus, SEM is useful to observe the compact bone structure and saw mark simply, rapidly, and clearly for practical use in forensic anthropology.

Key words: Compact bone structure, Saw mark, Scanning electron microscope 


\section{緒言}

骨の緻密質の組織構造は，白骨死体の人獣鑑別 ${ }^{1}$ や年齢推定 ${ }^{2}$ における指標の 1 つとして利用されて いる. 現在, 緻密質の観察には, 顕微 X 線法 ${ }^{1}$ や光 学顕微鏡3) 利用した手法があるものの, 明瞭な観 察像を得るための標本の作製は煩雑であり熟練を要 する．また，殺人事件などで死体が切断されている 場合, 切断器具の推定を目的として, 骨の切断面に 生じる Saw Mark と呼ばれる凹凸のある痕跡を詳 細に観察する必要がある4,5). しかし, 光学顕微鏡 によるSaw Mark の観察は, 焦点深度が浅く, 骨 の色調が妨げとなるため, 凹凸の確認には限界があ る.

走査型電子顕微鏡 (scanning electron microscope, SEM）は, 標本の表面構造の拡大観察に適した機 材であり, 近年の技術的な進歩により観察の条件設 定の自動化や観察に適合する対象物の多様化が進ん でいることから，標本の簡便な観察が可能となって いる。これまでにも，SEMを用いた骨の緻密質や Saw Mark の観察に関する報告はあるが6-10)，SEM を使用する利点についての詳細な検討はなされてい ない.

本研究では, 骨の緻密質およびSaw Mark の観 察に拈いて，SEMを用いた効果的な観察方法とそ のための簡便な骨の標本作製方法について検討し た. その結果, 短時間かつ簡便に明瞭な観察像が得 られたので報告する.

\section{材料および方法 \\ 1. 試料および機材}

ブタおよびウシの大腿骨（JA えひめアイパック スから提供されたもの）ならびにニワトリの上腕骨 （市販品）を試料とした（いずれも成獣骨であるが, 年齢の詳細および性別は不詳). 骨の切断器具は, 電動回転式カッター（Minimo，ミニター，構成： 電着ダイヤモンドディスク；直径 $45 \mathrm{~mm}$, モー ター； KM21H，打よびパワーパック；C301）打よ び手引き鋸(ハンディソー，神沢鉄工）を使用した。 骨の横断面を鏡面仕上げするための研磨材として, \#400，800，抢よび1,500の耐水研磨紙 (三共理化学)
ならびに\#4,000，8,000，および15,000のラッピン グフィルム（マルトー）を利用した，骨の洗浄は， 超音波洗浄機（DG-1， サンフレックス）で行った. SEM は，多くの沉用SEMで採用されている Everhart Thornley 検出器 (二次電子用) および半 導体検出器（反射電子用）を備えた，卓上型の JCM-6000 Plus（日本電子）を用いた。

\section{2. 標本の作製}

\section{2-1. 緻密質の観察のための標本}

ブタの骨において，3 種類の標本を用意した．先 ず，ブタの骨の骨幹中央部を，電動回転式カッター を用いて，骨の長軸に対し垂直方向に約 $1 \mathrm{~cm} の$ 厚 さになるように横断したもの. 次に，その横断面を 研磨材の目の粗い\#400から目の細かい\#15,000まで の段階的な水研ぎによって鏡面仕上げしたもの. 最 後に，鏡面仕上げの後に超音波洗浄を行ったものを それぞれ標本とした．ウシおよびニワトリの骨の標 本については, ブタの標本のうち良好な結果が得ら れた手法と同様に作製した。鏡面仕上げのための水 研ぎは，流水下において，平面に置かれたそれぞれ の研磨材で試料を十回程度研磨することにより行っ た。各標本は, 流水で十分に濯いだ後, 自然乾燥 (室温・ 1 時間程度）させた.

なお, ウシの標本は, 横断面の長径が約 $5 \mathrm{~cm}$ あ り，本研究で使用した SEM の試料台に収容できな かったことから，標本の一部（横断面の大きさ：約 $1.5 \mathrm{~cm} \times 1.0 \mathrm{~cm})$ を同カッターで切り取って観察し た、ブタおよびニワトリの標本は，横断面の長径 が，それぞれ約 $2.5 \mathrm{~cm}$ および約 $0.8 \mathrm{~cm}$ であったた め, そのまま試料台に載せて観察した.

\section{2-2. Saw Mark の観察のための標本}

ブタの骨の骨幹中央部を電動回転式カッターおよ び手引き鋸を用いて，それぞれ厚さが約 $1 \mathrm{~cm}$ にな るように横断したもの（長径：約 $2.5 \mathrm{~cm}$ ）を標本と した。なお，これらについては, 観察面の研摩は実 施していない.

\section{3. 標本の観察}

\section{3-1. 緻密質の観察}

ブタの標本を用いて, SEMの二次電子像 (secondary electron, SE image) ならびに反射電子 凹凸像（topographic, TOPO image）抒よび組成像 
(compositional, COMPO image) で，それぞれ緻 密質の組織構造を明瞭に確認できるかどうか検討し た。な抢，反射電子像は，通常，低真空状態で観察 するのに対し，二次電子像は一般的に高真空状態で 観察するため, 帯電現象11)によって適切な観察像が 得られない場合がある。そこで二次電子像について は，標本への導電性の高い金属（プラチナ）コーテ ィングの有無による観察像の比較も行った。本検討 で良好な結果が得られた観察条件において，ウシお よびニワトリの標本も観察し，動物種の識別が可能 かどうかを検討した。それぞれの標本の前処理およ び観察条件の詳細は Table のと抢りであり, 観察条 件のうち倍率は，各種動物の緻密質を低倍率から高 倍率まで観察した結果，人獣鑑別に有用な情報であ るハヴァース管の大きさや配置または網状の層板構 造を同時に確認することに適していた50倍で行っ た. また，観察条件のうち加速電圧についてはブタ の標本を用いて事前に予備実験を行い，二次電子像 では，プラチナ・コーティングの有無に関わらず, 緻密質内の腔所（ハヴァース管，骨小腔および層板 構造の空隙）が極端に明るくなるエッジ効果 ${ }^{11)}$ が抑 えられた $5 \mathrm{kv}$ を選択し，反射電子像では比較的明 瞭な観察像が得られた $15 \mathrm{kv}$ を選択した。

\section{3-2. Saw Mark の観察}

電動回転式カッターおよび手引き鋸で横断したブ タの標本を反射電子凹凸像で観察した。 それぞれの 観察条件の詳細については Tableのと抢りである.

\section{結果および考察}

SEM による観察では，電子線を標本に照射した 際に発生する二次電子および反射電子と呼ばれる信 号が主に利用される。二次電子は，発生する深さが 標本表面から $10 \mathrm{~nm}$ 程度と浅く, 表面形状に大きく 依存した信号であるため，形態観察に適しており， その情報は二次電子像として形成される. 反射電子 は，標本表面の凹凸と標本を構成する物質の平均原 子番号に大きく依存して発生する信号であることか ら，それぞれの情報は凹凸像と組成像に分離されて 表現される11,12)。そこで，SEMの二次電子像なら びに反射電子凹凸像および組成像で，ブタの標本の 緻密質を観察し，ハヴァース管（Haversian canal), 骨小腔 (bone lacuna) 抢よび層板構造 (lamellar structure) などの組織構造が明瞭に確認 できるかどうかを検討した．緻密質の組織構造の観 察には, SEMに限らず光学顕微鏡を利用する場合 であっても，標本の観察面を研磨することが一般的

Table Sample conditions and scanning parameter settings.

\begin{tabular}{|c|c|c|c|c|c|c|c|c|}
\hline \multirow[b]{2}{*}{ No. } & \multirow[b]{2}{*}{ Sample } & \multicolumn{3}{|c|}{ Treatments } & \multicolumn{3}{|c|}{ Scanning parameter settings*) } & \multirow[b]{2}{*}{ Fig. } \\
\hline & & Polishing & $\begin{array}{c}\text { Ultrasonic } \\
\text { cleaning }\end{array}$ & $\begin{array}{c}\text { Metal } \\
\text { coating }\end{array}$ & Vacuum & Image & $\begin{array}{c}\text { Accelerating } \\
\text { voltage }\end{array}$ & \\
\hline 1 & \multirow{3}{*}{ Pig } & \multirow{3}{*}{+} & $(-)$ & + & \multirow{3}{*}{ High } & \multirow{3}{*}{$\mathrm{SE}$} & \multirow{3}{*}{$5 \mathrm{kV}$} & $1 \mathrm{~A}$ \\
\hline 2 & & & $(-)$ & $(-)$ & & & & 1B \\
\hline 3 & & & + & $(-)$ & & & & $1 \mathrm{C}$ \\
\hline 4 & \multirow{2}{*}{ Pig } & \multirow{2}{*}{+} & $(-)$ & \multirow{2}{*}{$(-)$} & \multirow{2}{*}{ Low } & \multirow{2}{*}{ TOPO } & \multirow{2}{*}{$15 \mathrm{kV}$} & $2 \mathrm{~A}$ \\
\hline 5 & & & + & & & & & $2 B$ \\
\hline 6 & \multirow{3}{*}{ Pig } & + & $(-)$ & \multirow{3}{*}{$(-)$} & \multirow{3}{*}{ Low } & \multirow{3}{*}{ COMPO } & \multirow{3}{*}{$15 \mathrm{kV}$} & $3 \mathrm{~A}$ \\
\hline 7 & & + & + & & & & & $3 B$ \\
\hline 8 & & $(-)$ & $(-)$ & & & & & 4 \\
\hline 9 & Cattle & \multirow{2}{*}{+} & \multirow{2}{*}{$(-)$} & \multirow{2}{*}{$(-)$} & \multirow{2}{*}{ Low } & \multirow{2}{*}{ COMPO } & \multirow{2}{*}{$15 \mathrm{kV}$} & $5 \mathrm{~A}$ \\
\hline 10 & Chicken & & & & & & & $5 \mathrm{~B}$ \\
\hline 11 & Pig (power saw cutting) & \multirow{2}{*}{$(-)$} & \multirow{2}{*}{$(-)$} & \multirow{2}{*}{$(-)$} & \multirow{2}{*}{ Low } & \multirow{2}{*}{ TOPO } & \multirow{2}{*}{$15 \mathrm{kV}$} & $6 \mathrm{~A}$ \\
\hline 12 & Pig (hand saw cutting) & & & & & & & $6 \mathrm{~B}$ \\
\hline
\end{tabular}

*) For all samples, the other parameters of scanning parameter setting were set as follows: filament brightness; high, probe current; high, working distance; $19 \mathrm{~mm}$, and magnification; 50-fold. 
である1,3,6,8).したがって，鏡面仕上げした標本を 二次電子像で観察した結果, 金属コーティングの有 無に関わらず，同等の観察像（Fig. 1A および B ) が得られたことから, 標本には導電性があり, 金属 コーティングは不要と考えられた. しかしながら, それらの組織像はともに八ヴァース管およびブタや ウシなどの偶踵類に特徵的な網状の層板構造13)の一 部は観察されるものの骨小腔は不明瞭であった。そ こで, 緻密質内の腔所に残存する骨粉や研磨材の微 粒子を除去するために超音波洗浄を行った標本を観 察したところ，八ヴァース管抢よび層板構造ととも に骨小腔も明瞭に確認することができた（Fig. 1C).

次に, 鏡面仕上げした標本を反射電子像凹凸像で 観察した結果，骨小腔だけでなくハヴァース管およ び層板構造も不明瞭であった（Fig. 2A）。そこで, 超音波洗浄を行った標本を観察したところ, 緻密質 内の腔所は, 確認できるようになったものの, 二次 電子像 (Fig. 1C) と比較して不明瞭であった (Fig. 2B).

一方, 反射電子組成像では, 鏡面仕上げした標本 （Fig. 3A）は，超音波洗浄を行った標本（Fig. 3B） よりも, 明確に確認できる骨小腔の数がやや劣るも のの, 二次電子像（Fig. 1C）と同様にハヴァース 管, 骨小腔および層板構造が明瞭に観察された。

反射電子凹凸像および組成像は，ともに標本から 放出された同じ反射電子を利用しているが，検出し た反射電子の演算方法で，それぞれの観察像が異な る. その原理として, 標本から放出された反射電子 は, 光軸に対して対称な位置に設置された二つの同 型の検出器によって感知される.ここで, それぞれ の検出された信号の差を取ると, 照明効果と呼ばれ る一方の検出器から照明を当てたような像が得られ て標本表面の凹凸が観察でき (凹凸像), 信号の和 を取ると照明効果がなくなり凹凸は確認されなくな るものの, 標本表面の組成の違いが観察できるよう になる (組成像 $)^{11,14)}$. 本検討では, 反射電子組成 像は, 凹凸像之比較して, 緻密質内の腔所に残存す る骨粉や研磨材の微粒子からの反射電子の影響が少 なく, ハヴァース管, 骨小腔抢よび層板構造の空隙 の明瞭な観察像を得られることが確認された。ま
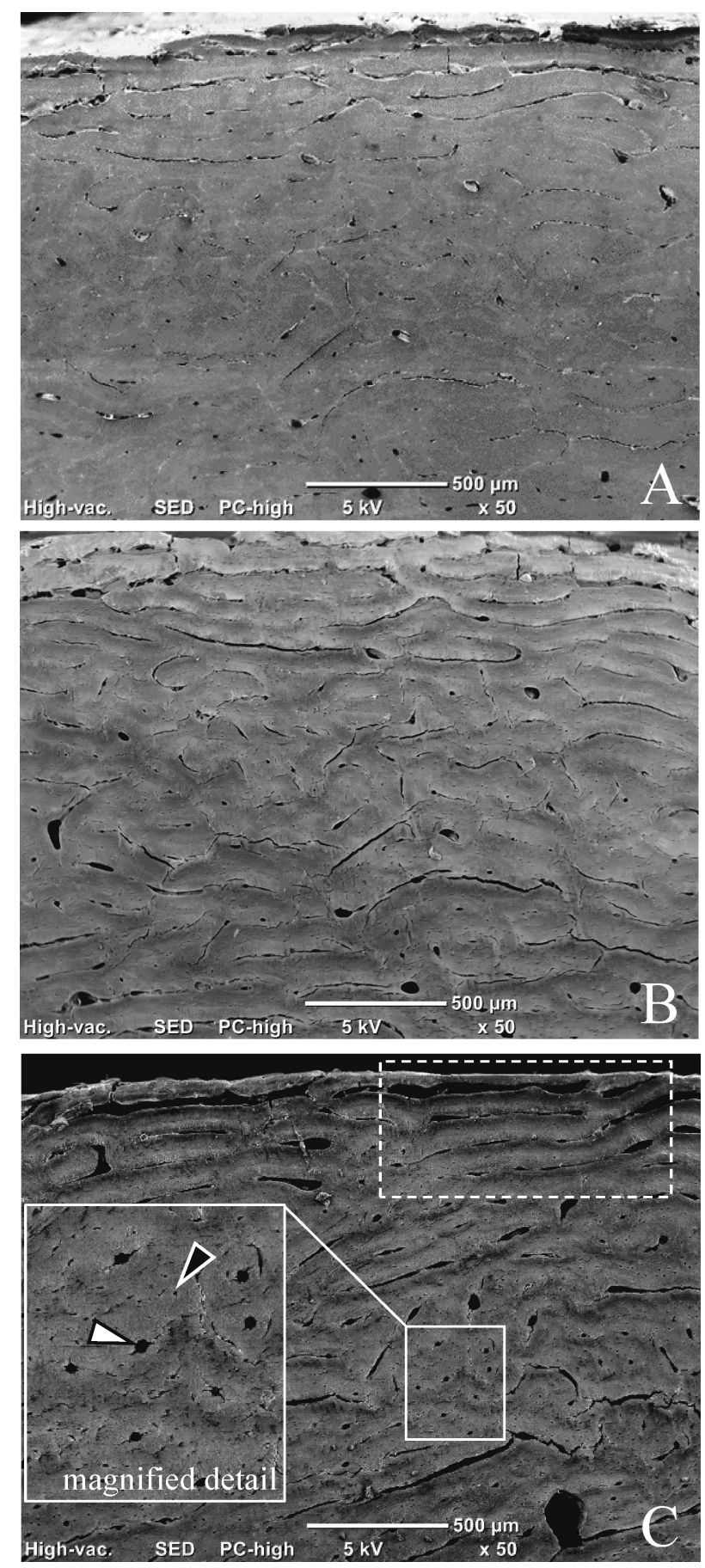

Fig. 1 SE images of the compact bone structure of pig. As typical examples, white arrowhead shows a Haversian canal, black arrowhead shows a bone lacuna, and the area enclosed by the dotted line shows a lamellar structure.

A: platinum sputter coating, B: no metal coating, C: ultrasonic cleaning and no metal coating 

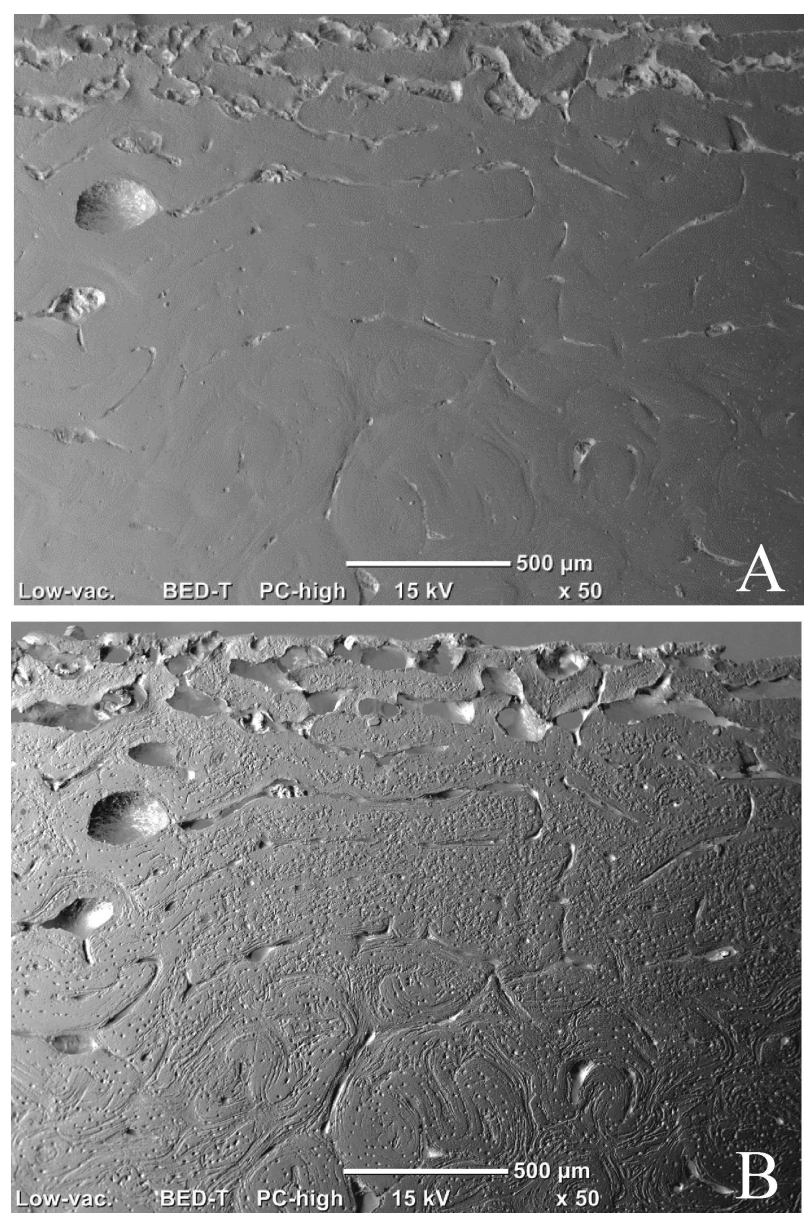

Fig. 2 TOPO images in backscattered electron mode of the compact bone structure of pig before (A) and after (B) ultrasonic cleaning.

た，鑑定実務では，焼かれた骨や土中に埋まってい た骨を検査する場合もあり，これらの骨は，脆弱で あり，超音波洗浄で損壊する危険性がある。実際の 鑑定を考慮した場合, 資料の破壊は可能な限り避け ることが望ましい，以上のことから，SEMによる 緻密質の簡便かつ明瞭な観察には，鏡面仕上げのみ を行った標本を利用できる反射電子組成像が最も適 していた.

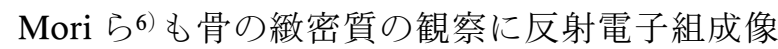
を利用しているが，その標本は骨の切片を樹脂包埋 して作製している，一方，我々の手法では，標本の 作製において樹脂包埋などの煩雑な作業をすること なく，簡便な研磨作業の久で Mori らの手法と同等 の明瞭な観察像が得られた。
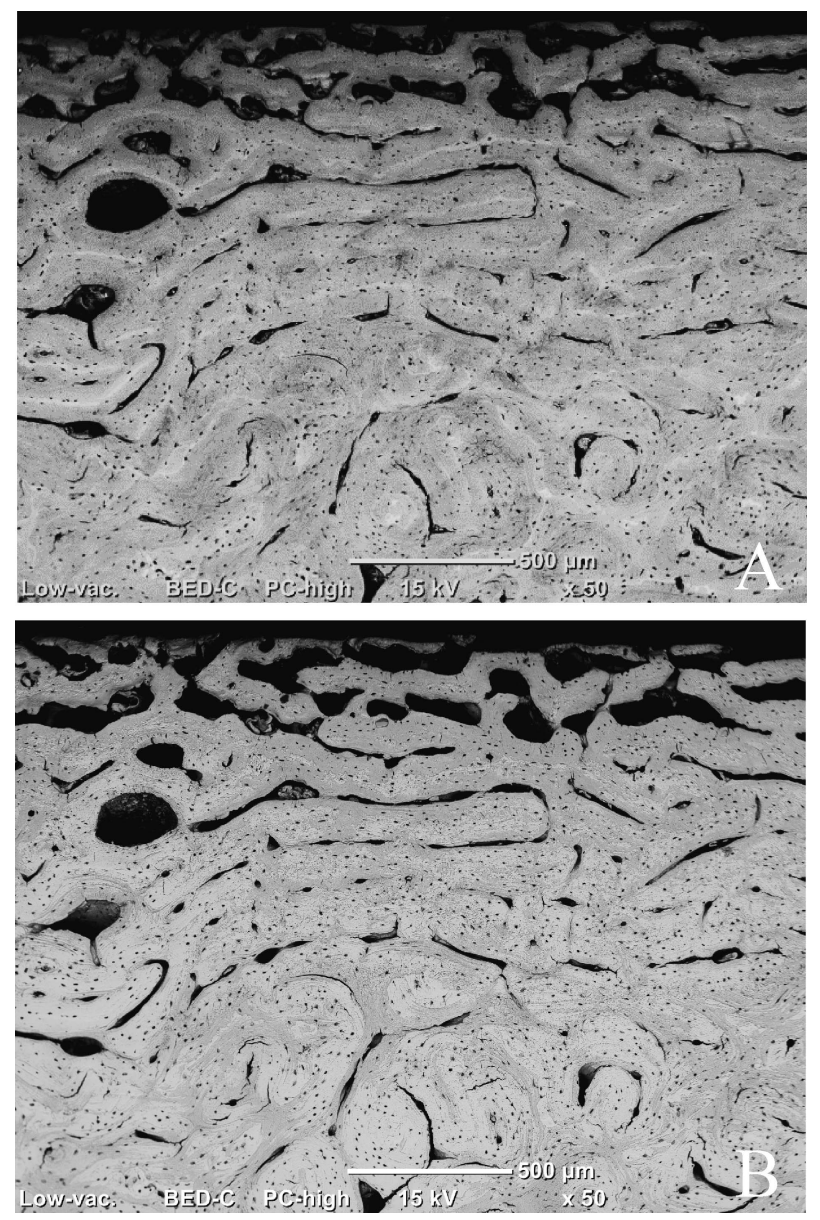

Fig. 3 COMPO images in backscattered electron mode of the compact bone structure of pig before (A) and after (B) ultrasonic cleaning.

ここで，さらなる手法の簡略化を想定して，標本 の研磨作業の省略を試みたが，研磨をしない場合， 層板構造の一部は確認できたものの, ハヴァース管 や骨小腔は不明瞭となった（Fig. 4).したがって， 緻密質の観察には研磨作業による鏡面仕上げが必要 不可欠であるが, 今回実施した\#15,000までの研磨 は数分間の作業で完了するため, 実務作業に大きな 支障はないと考えられる.さらに，ブタ以外の動物 の標本についても反射電子組成像で観察したとこ ろ, ウシの標本では, 網状の層板構造が認められ (Fig. 5A)， ニワトリの標本では，ハヴァース管の 密な分布が確認された（Fig. 5B)。これらは, 猪井 らの報告1)による顕微 X 線法を用いた各動物の組織 像と類似の特徵を有していたことから，本手法は， 


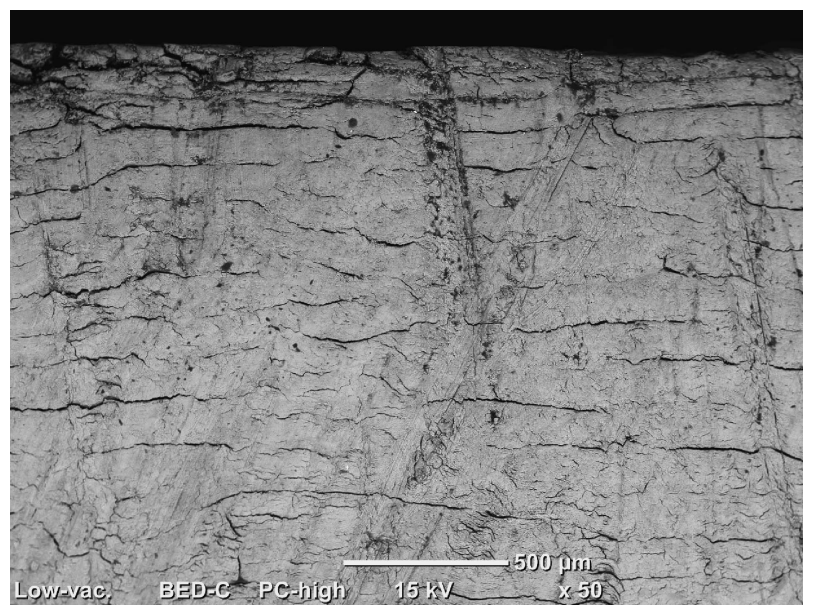

Fig. 4 COMPO image in backscattered electron mode of the compact bone structure of pig. The sample was not polished.

各種動物の特徵を反映した緻密質の組織構造を観察 できるものと考えられた。

白骨死体の人獣鑑別は, 事件性を判断する上で重 要であり，頭蓋骨や骨盤など多くの形態学的特徵を 有する骨の大部分が残存していれば迅速に判断でき るが，長骨の一部分のみといった部分骨では容易で はない．部分骨であっても，DNA 検査により人獣 鑑別は可能であるが，その検査には数日を要する. さらに，部分骨では，微量または陳旧化の影響によ り DNA 検査による人獣鑑別が困難な場合も多い。 このような場合，本手法を利用し骨の緻密質の組織 構造を観察することができれば，迅速かつ簡便な人 獣鑑別が可能になると考えられる.

最後に, 反射電子凹凸像は, 二次電子像と比較し て，照明効果により，なだらかな凹凸も識別しやす い14)ことから，凹凸像で Saw Mark を観察した結 果，それぞれの切断方法を反映していると思料され る観察像が得られた。電動回転式カッターによる切 断面には，切断方向と直交するような多数の互いに 平行する条線が認められ，その表面形状は比較的滑 らかであった（Fig. 6A）。一方，手引き鋸の切断面 にも，切断方向と直交するような幾筋かの条線があ ったものの，切断が進行する途中で条線の向きが明 確に変化しているものが確認された。ささらに，その 表面形状は, 電動回転式カッターによる切断面と比
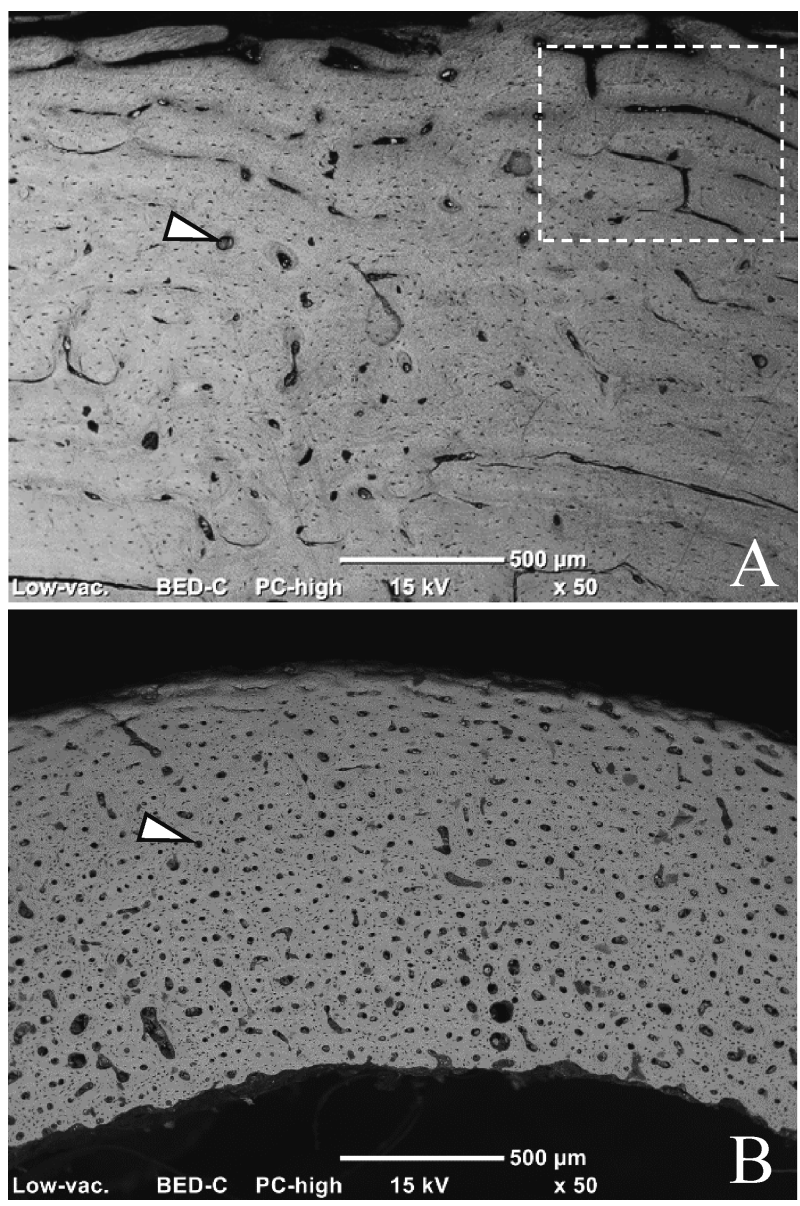

Fig. 5 COMPO images in backscattered electron mode of the compact bone structure of animals. As typical examples, white arrowheads show a Haversian canal and the area enclosed by the dotted line shows a lamellar structure.

A: cattle, B: chicken

較して粗造であり，大小不揃いの凹凸が多数観察さ れた (Fig. 6B)。実際の鑑定では，再鑑定を考慮し て，資料の污損を可能な限り回避すべきである。二 次電子像で Saw Mark を観察する場合，切断面の 凹凸を明確に確認するためには，金属コーティング が必要であったため，污損の少ない凹凸像による観 察が望なしいと考えられる。

以上のことから，白骨死体の鑑定において， SEM は観察目的に応じて利用する観察モード（反 射電子凹凸像または組成像）を選択すれば，骨の表 面の凹凸だけでなく，簡便な研磨作業のみで骨の緻 密質の組織構造も観察できることが示され，非常に 

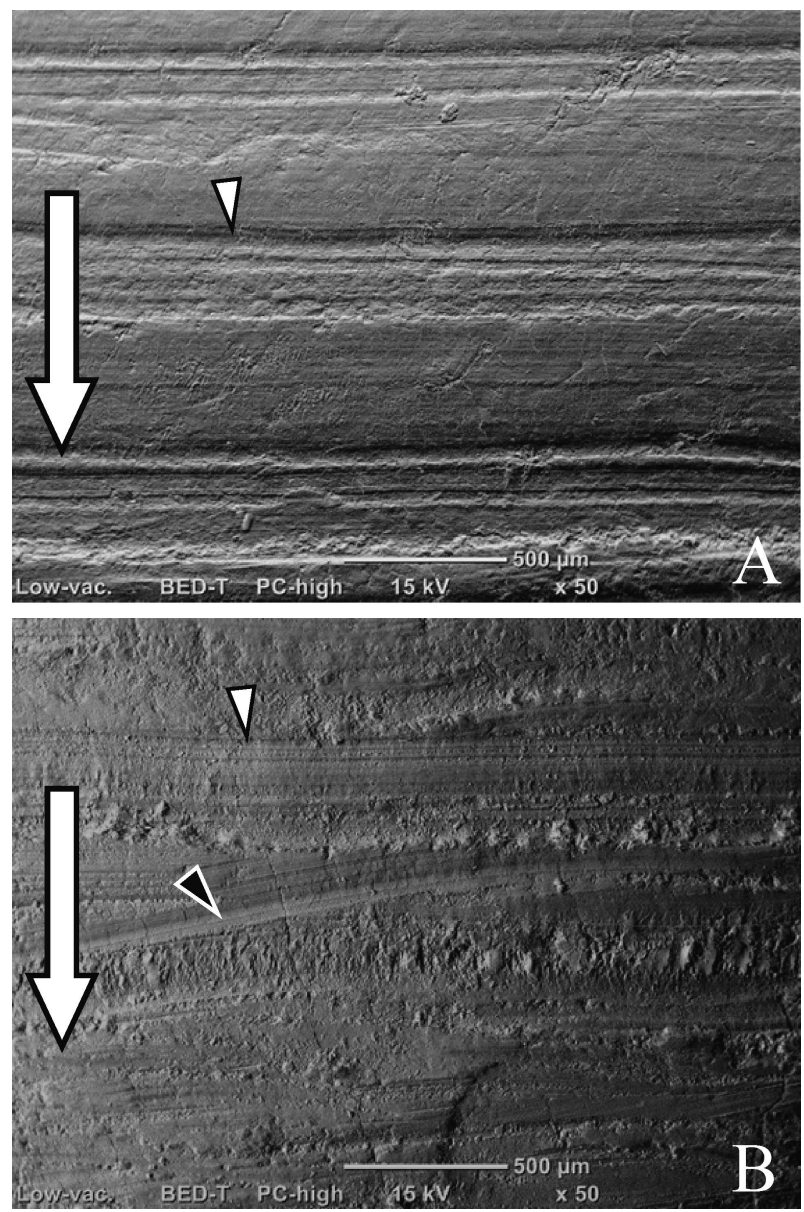

Fig. 6 TOPO images in backscattered electron mode of saw marks on cross sections of pig bone. White arrows show a direction of saw progress. As typical examples, white arrowheads show a saw stria perpendicular to the direction of saw progress and black arrowhead shows a saw stria non-perpendicular to the direction of saw progress.

A: power saw, B: hand saw

有用であると考えられた。

\section{謝 辞}

本稿を執筆するにあたり，ご助言を賜った愛媛大 学大学院農学研究科生命機能学専攻動物細胞工学教 育分野西甲介准教授に深く感謝申し上げます.

\section{文 献}

1）猪井 剛, 吉野峰生, 瀬田季茂, ヒトと各種 動物の長骨組織像の顕微 X 線学的研究とその法
科学的応用. 科学警察研究所報告法科学編, 47, 92-101, 1994.

2）瀬田季茂, 吉野峰生, 年齢の推定, 白骨死体 の鑑定. pp. 153-278，令文社，東京， 1990 .

3）瀬田季茂, 骨組織の反射顕微鏡による形態学 的観察. 科学警察研究所報告, 21, 99-105, 1968.

4) Symes S. A., Morphology of saw marks in human bone : identification of class characteristics [http://trace.tennessee.edu/utk_graddiss/1253/] accessed Apr. 01, 2019.

5) Marciniak S. M., A Preliminary assessment of the identification of saw marks on burned bone, $J$. Forensic Sci., 54(4), 779-785, 2009.

6) Mori R., Kodaka T., Soeta S., Sato J., Kakino J., Hamato S., Takaki H., and Naito Y., Preliminary study of histological comparison on the growth patterns of long-bone cortex in young calf, pig, and sheep, J. Vet. Med. Sci. 67(12), 1223-1229, 2005

7) Hillier M. L. and Bell L. S., Differentiating human bone from animal bone: A review of histological methods, J. Forensic Sci., 52 (2) , 249-263, 2007.

8）網塚憲生, 本郷裕美, 坪井香奈子, 長谷川智 香, 山本知真也，原口真衣，骨の細胞に拈ける 組織学的 ·微細構造学的知見, 顕微鏡, $50(3)$, 191-196, 2015.

9) Alunni-Perret V., Muller-Bolla M., Laugier J.-P., Lupi-Pégurier L., Bertrand M.-F., Staccini P., Bolla M., and Quatrehomme G., Scanning electron microscopy analysis of experimental bone hacking trauma, J. Forensic Sci. 50(4), 796-801, 2005.

10) Kooi R. J. and Fairgrieve S. I., SEM and stereomicroscopic analysis of cut marks in fresh and burned bone, J. Forensic Sci. 58 (2) , 452-458, 2013.

11）日本電子, 電子線と試料の相互作用に起因す る事柄，走査電子顕微鏡による観察の手引き。 pp. 5-17，日本電子，東京， 2000 . 
12）日本電子, 用語, 走査電子顕微鏡による観察 の手引き. pp. 34, 日本電子, 東京, 2000.

13) Mulhem D. M. and Ubelaker D. H., Differentiating human from nonhuman bone microstructure, Bone histology: An anthropological perspec- tive. pp.109-134, CRC press, Florida, 2012.

14）小野昭成，柴田昌照，各種 SEM における電 子の検出法と像の見え方の違い, 顕微鏡, 43 (3), 162-165, 2008. 